\title{
Gene expression of the GH receptor in subcutaneous and intraabdominal fat in healthy females: relationship to GH-binding protein
}

\author{
Sanne Fisker, Betina Hansen, Jens Fuglsang ${ }^{3}$, Kurt Kristensen $^{1}$, Per Ovesen ${ }^{3}$, Hans Ørskov ${ }^{2}$ and \\ Jens Otto Lunde Jørgensen \\ Medical Department M (Endocrinology and Diabetes), ${ }^{1}$ Department of Endocrinology and Metabolism, ${ }^{2}$ Institute of Experimental Clinical Research and \\ ${ }^{3}$ Department of Gynecology and Obstetrics, Aarhus University Hospital, DK-8000 Aarhus C, Denmark \\ (Correspondence should be addressed to S Fisker; Email: sanne.fisker@dadlnet.dk)
}

\begin{abstract}
Objective: Circulating GH-binding protein (GHBP) is produced by proteolytical cleavage of the extracellular part of the GH receptor (GHR) and is positively correlated to the amount of body fat. To test the hypothesis that adipose tissue may contribute to the production of circulating GHBP, we compared gene expression of two GHR isoforms in adipose tissue with serum GHBP concentrations in healthy females.

Design: Twenty-two healthy females undergoing surgery for benign gynecological conditions were included in the study.

Methods: During surgery, s.c. and intraabdominal fat biopsy samples were taken. Gene expression of the full-length GHR and a truncated GHR (GHRtr) was assessed by RT-PCR relative to the expression of $\beta$-actin.

Results: The full-length GHR was expressed to a much higher level than GHRtr in both tissues. The levels of both GHR and GHRtr mRNA were similar in intraabdominal and s.c. adipose tissues. Surprisingly, concentrations of circulating GHBP were negatively correlated to the levels of mRNA transcripts of both the full-length GHR and GHRtr in intraabdominal fat. Whole body resistance (as a measure of lean body mass) was positively correlated to mRNA levels for both GHRs in intraabdominal fat. Conclusions: (i) The full-length GHR is expressed to a much higher level than GHRtr in s.c. as well as visceral abdominal fat; (ii) the observation of a significant correlation between GHR expression and GHBP levels further emphasizes the link between adipose tissue and GHBP; (iii) it remains, however, to be demonstrated whether circulating GHBP is produced to a significant degree by adipose tissue.
\end{abstract}

European Journal of Endocrinology 150 773-777

\section{Introduction}

Circulating growth hormone (GH)-binding protein (GHBP) originates from GH receptors (GHRs) (1), which exist in a predominating full-length form and a truncated form (GHtr) lacking $97.5 \%$ of the intracellular part (2). The regulation and function of the highaffinity GHBP are not fully known. The tissue origin of circulating GHBP is also unknown, although the liver has been suggested as the main source due to a high GHR density (3, 4). The strong positive correlations found between adipose tissue mass and GHBP has also raised the suggestion that adipose tissue contributes to circulating GHBP. To further explore these hypotheses, studies have evaluated GHR status in different tissues, either by measuring GH binding to the receptor or by determining gene expression of GHRs. In liver cirrhosis normal and decreased mRNA transcripts have been described $(5,6)$, while circulating GHBP is normal or low (7-10). Hermansson et al.
(11) found a decrease in GHR mRNA transcripts in skeletal muscle after elective surgery accompanied by a decrease in GHBP levels. We have previously shown that expression of the full-length GHR in skeletal muscle, and expression of GHRtr in s.c. adipose tissue, increase after GH treatment accompanied by a decrease in circulating GHBP levels (12). So far no unambiguous relationship between GHR status and circulating levels of GHBP has been described.

In the present study we examined gene expression of two GHRs in s.c. and intraabdominal adipose tissue in healthy females and their relationship to circulating GHBP.

\section{Subjects and methods}

\section{Subjects}

Twenty-two healthy females were included in the study after written informed consent. The study was 
approved by the regional Ethics Committee. The females were aged $47.5 \pm 1.5$ years with a normal body mass index (BMI) $\left(24.0 \pm 2.9 \mathrm{~kg} / \mathrm{m}^{2}\right)$ (means \pm S.E.M.). Serum insulin-like growth factor-I (IGF-I) levels were $115 \pm 8 \mu \mathrm{g} / \mathrm{l}$. The participants were referred to the Department of Gynecology and Obstetrics for elective abdominal hysterectomy because of fibromyoma, metrorragia, endometriosis or carcinoma in situ. The day before the operation non-fasting blood samples were drawn; serum was stored at $-20^{\circ} \mathrm{C}$ until analyses. For determination of lean body mass, whole body resistance was measured by bioelectrical impedance using a BIA 101 (RJL-Systems, Detroit, MI, USA). Height and weight was measured for calculation of BMI (weight in $\mathrm{kg} /(\text { height in } \mathrm{m})^{2}$ ).

\section{Biopsy samples}

During the operative procedure adipose tissue biopsy samples $(1-2 \mathrm{~g})$ were taken from intraabdominal adipose tissue and from s.c. adipose tissue and stored in anonymized form. Patients fasted for $10-12 \mathrm{~h}$ before the operation. Tissue samples were immediately frozen in liquid nitrogen and thereafter stored at $-80^{\circ} \mathrm{C}$ until analyses.

\section{Immunoassays}

GHBP was measured with an in-house immunofunctional immunometric assay (13); IGF-I analyses were performed in an in-house RIA after extraction of binding proteins as previously described (14).

\section{GHR mRNA quantification}

Isolation of RNA Total RNA was isolated using the TriZol reagent (Gibco BRL, Life Technologies, Roskilde, Denmark). RNA was quantified by measuring absorbency at 260 and $280 \mathrm{~nm}$, and the integrity of the RNA was checked by visual inspection of the two ribosomal RNAs, $18 \mathrm{~S}$ and 28S, on an agarose gel.

Real-time RT-PCR measurement of GHR or GHRtr mRNA RNA was reverse transcribed with reverse transcriptase and random hexamer primers at $23^{\circ} \mathrm{C}$ for $10 \mathrm{~min}, 42^{\circ} \mathrm{C}$ for $60 \mathrm{~min}$, and $95^{\circ} \mathrm{C}$ for $10 \mathrm{~min}$ according to the manufacturer's instructions (GeneAmp RNA PCR Kit; Perkin Elmer Cetus, Norwalk, CT, USA). Then, PCR-mastermix containing the specific primers, Hot Star Taq DNA polymerase, and SYBR-Green PCR buffer were added. All samples were determined as duplicates. The GHR and GHtr primers amplified products of 158 and $132 \mathrm{bp}$ respectively. The sense primer sequences were as follows $5^{\prime}$-ATTTTCTAAACAGCAAAGGA-3' and 5'-ATTTTCTAAACAGCAAAGTT$3^{\prime}$, for GHR and GHRtr respectively (2).

As a house-keeping gene $\beta$-actin was amplified using the following primers: 5'-ACGGGTCACCCACACTGTGC and 5'-CTAGAAGCATTTGCGGTGGACGATG. Real-time quantification of GHR or GHRtr in relation to $\beta$-actin mRNA was performed using a SYBR-Green PCR assay and an iCycler PCR machine (Bio-Rad Laboratories Inc., Hercules, CA, USA) (15). In brief, GHR or GHRtr mRNA and $\beta$-actin mRNA were amplified in separate tubes at $95^{\circ} \mathrm{C}$ for $10 \mathrm{~min}$ and thereafter repeating cycles of $95^{\circ} \mathrm{C}$ for $30 \mathrm{~s}, 57^{\circ} \mathrm{C}$ for $30 \mathrm{~s}$ and extension at $72{ }^{\circ} \mathrm{C}$ for $60 \mathrm{~s}$. During the extension step, the increase in fluorescence was measured in real-time. Data were obtained as $\mathrm{C}_{\mathrm{T}}$ values (threshold cycle). $\mathrm{C}_{\mathrm{T}}$ was defined as the cycle number at which the fluorescence reached 10 times the standard deviation of the baseline fluorescence. Relative gene expression was calculated using the formula $1 / 2^{(\mathrm{CT}(\mathrm{GHR})-\mathrm{CT}(\beta \text {-actin) })}$, essentially as described in the User Bulletin \#2 1997 from Perkin Elmer.

\section{Statistics}

The statistic program SPSS 10.0 for Windows was applied. Student's t-test was performed to compare levels of mRNA. Pearson correlation analyses and multiple regression analyses were performed to relate variables. Results are expressed as means \pm s.E.M. A significance level of 0.05 was used.

\section{Results}

\section{mRNA expression}

The level of expression of the full-length GHR in intraabdominal fat and s.c. fat was identical $(P=0.13), \quad$ and significantly intercorrelated $(r=0.450, P=0.035)$ (Fig. 1$)$. The GHRtr was also expressed to the same degree in the two regions $(P=0.86)$ (Fig. 1), but with no correlation between them $(r=0.274, P=0.218)$. The expression of GHR was approximately 400-500 times higher as compared with GHRtr in both intraabdominal and s.c. fat, and there was no difference in the ratios of GHR relative to GHRtr in the two tissues (data not shown). The expressions of GHR and GHRtr were correlated in intraabdominal fat $(r=0.662, P=0.001)$ but not significantly so in s.c. fat $(r=0.411, P=0.057)$ (Fig. 2$)$.

\section{GHBP}

The levels of circulating GHBP were negatively correlated to the expression of both the full-length GHR and GHRtr in intraabdominal fat, whereas there was no significant correlation between GHBP and the expression of the two receptor types in s.c. fat (Fig. 3).

We calculated the product BMI $\times$ mRNA levels and related this to GHBP levels. For intraabdominal fat the product $\mathrm{BMI} \times \mathrm{mRNA}$ correlated negatively to $\mathrm{GHBP}$ levels for both GHR and GHRtr $(r=-0.430$, $P=0.046 ; \quad r=-0.447, \quad P=0.033)$, whereas the 

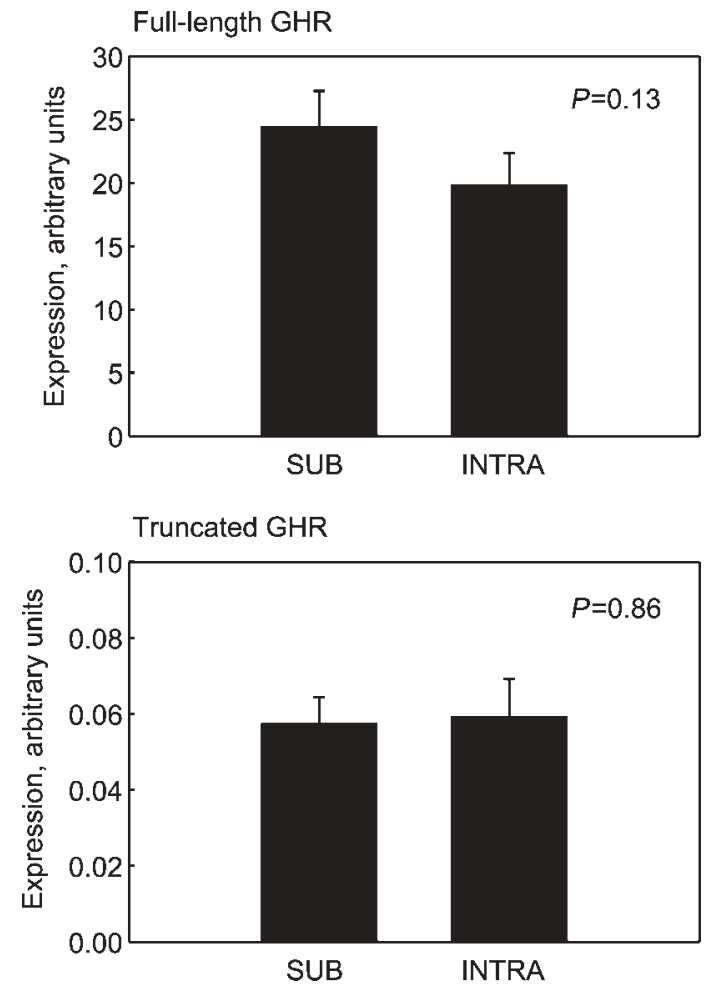

Figure 1 Top panel: gene expression of the full-length GHR in s.c. (SUB) and intraabdominal (INTRA) adipose tissue. Bottom panel: gene expression of GHRtr in s.c. and intraabdominal adipose tissue.

products calculated for s.c. fat were not correlated to GHBP levels.

\section{Body composition}

Whole body resistance (an estimate of lean body mass) was positively correlated to mRNA levels for both the full-length GHR and GHRtr in intraabdominal fat $(r=0.462, \quad P=0.030$ and $r=0.449, \quad P=0.036$ respectively), whereas whole body resistance was not related to the expression of GHR in s.c. fat.

BMI and GHBP levels were not significantly correlated (Fig. 4). However, controlling for age, BMI and GHBP correlated significantly $(r=0.548, P=0.008)$.

The levels of IGF-I $(115 \pm 7 \mu \mathrm{g} / \mathrm{l})$ were not correlated to GHBP, body composition or expression of GHRs (data not shown).

\section{Discussion}

We compared gene expression of two different GHRs, i.e. full-length GHR and GHRtr lacking $97.5 \%$ of the intracellular part, in s.c. and intraabdominal fat in healthy females, and examined their relationship to circulating GHBP levels and body composition. We found (i) no regional differences in the expression of the receptors, (ii) a negative correlation between mRNA
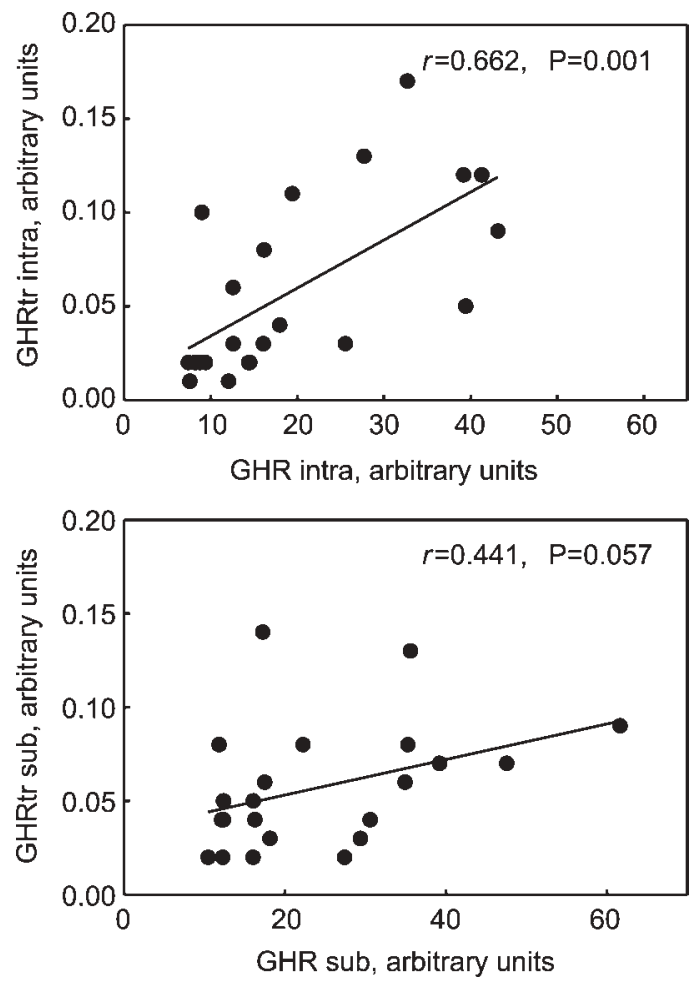

Figure 2 Relationship between gene expression of the full-length GHR and GHRtr in intraabdominal adipose tissue (intra) (top panel) and in s.c. adipose tissue (sub) (bottom panel).

transcripts for the two receptors in intraabdominal adipose tissue and levels of circulating GHBP, (iii) a positive correlation between the expression of the two different receptor types in intraabdominal adipose tissue, and (iv) a positive correlation between lean body mass and mRNA levels in intraabdominal fat.

Circulating GHBP is produced from proteolytical cleavage of GHR, which exists in at least three different forms in humans: an exon-3-retaining receptor and an exon-3-deleted receptor, which are called full-length GHRs (16), and GHRtr, which lacks $97.5 \%$ of the intracellular domain (2). This latter receptor has been shown to possess an increased ability to produce GHBP in in vitro studies $(2,17)$, which adds interesting aspects to this receptor as regards the origin of GHBP in the circulation. The significance of the GHRtr is, however, not clear. The abundance of the receptor has generally been found low relative to the full-length receptor $(2,3,18)$, which is also confirmed in the present study.

In a previous study in healthy adults (19) we found a strong positive correlation between GHBP and the amount of intraabdominal fat. We therefore suggested that GHRs in adipose tissue significantly contribute to circulating GHBP. In a subsequent study, however, we found no correlation between mRNA levels for GHR or GHRtr and circulating GHBP in s.c. fat or in striated muscle in GH-deficient (GHD) patients. GH replacement therapy did increase levels of mRNA for GHR in striated 

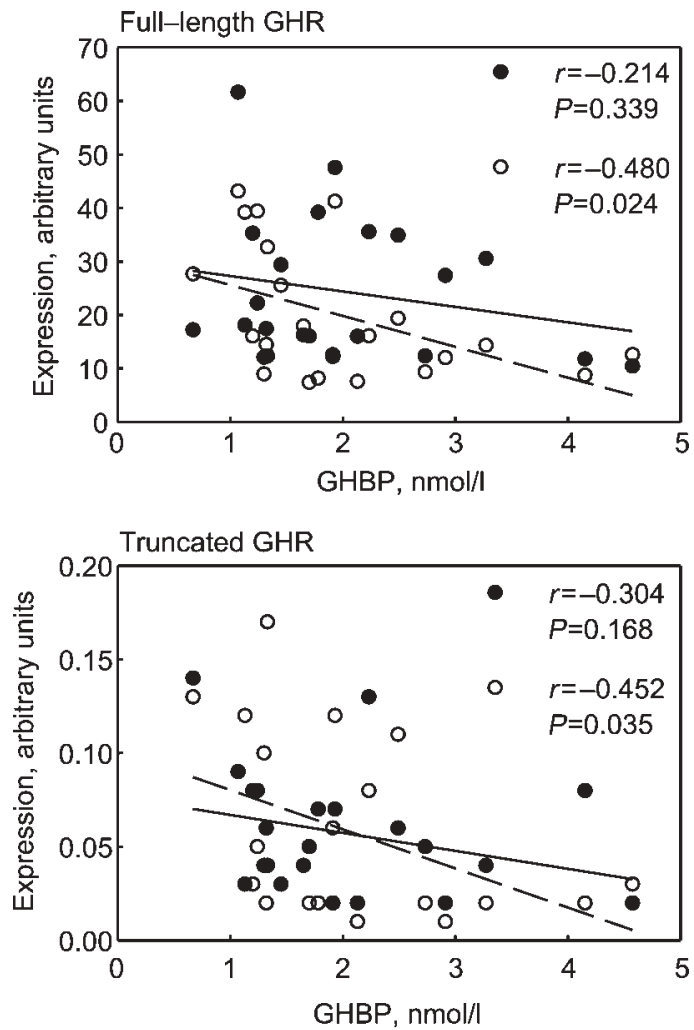

Figure 3 Top panel: relationship between GHBP and gene expression of the full-length GHR in s.c. adipose tissue $(\bullet$, regression solid-lined) and in intraabdominal adipose tissue $(\bigcirc$, regression dashed-lined). Bottom panel: relationship between GHBP and gene expression of GHRtr receptor in s.c. adipose tissue $(\bullet$, regression solid-lined) and in intraabdominal adipose tissue $(\bigcirc$, regression dashed-line).

muscle but not in s.c. fat, whereas expression of GHRtr in s.c. fat was significantly increased. Still, no correlation to GHBP was found (12). We expected to find a positive correlation between GHRs in intraabdominal fat and GHBP; by contrast, we found a negative correlation between GHR and GHBP as well as between GHRtr and GHBP levels. In a study of GH responsiveness in GHD adult patients Johannsson et al. (20)

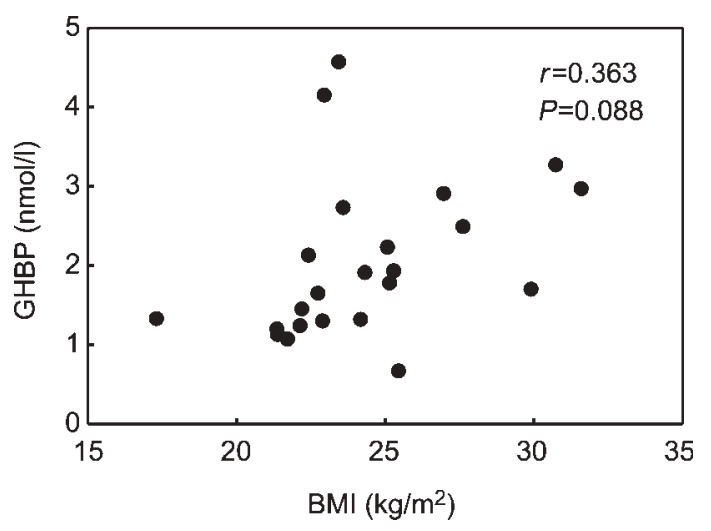

Figure 4 Relationship between BMI and GHBP. found a negative correlation between levels of GHBP and responsiveness. One of the mechanisms behind this finding could be an inverse relationship between levels of GHBP and GHR abundance in some tissues, among them intraabdominal adipose tissue.

Since GHBP levels are positively correlated to BMI, we calculated the product of BMI and mRNA levels for the two receptors to test whether this indirect measure of 'total' GHR mRNA in adipose tissue would reveal a positive correlation to GHBP levels. Still, the negative correlation between 'total' mRNA levels for GHR and GHRtr in intraabdominal was present.

We were not able to assess GHR protein, and the degree to which GHR mRNA is translated into protein is therefore unknown. Thus a major problem exists in predicting GHR levels from RNA levels, which has to be taken into consideration in the interpretation of the results.

The regulation of GHR expression and the proteolysis of GHRs may be tissue-specific, since we found no relationship between GHBP and GHR mRNA in s.c. fat. The much closer relationship between GHBP and GHRs in intraabdominal fat may be attributable to the amount of intraabdominal fat relative to s.c. We did, however, find a trend of positive correlation between gene expression of the two receptors in both intraabdominal and in s.c. adipose tissue, suggesting a co-expression of the two different receptor types.

One explanation for the negative correlation between mRNAs for GHRs and GHBP could be that receptors in adipose tissue do not contribute to circulating GHBP. So far it is not clear whether GHBP from peripheral tissues only plays a 'local role', or whether the liver is the major supplier of circulating GHBP. In previous studies differing results have been obtained regarding the relationship between liver function, GHR gene expression, and levels of GHBP $(6,8-10)$. Donagny et al.(6) described that gene expression of GHR was decreased in cirrhosis whereas levels of GHBP were decreased only in patients with severe cirrhosis, and no correlation between GHBP and mRNA levels was found. We investigated 38 patients with cirrhosis and found normal levels of GHBP with no correlation to disease severity (7). It is not clear whether changes in peripheral tissues and the liver are parallel or whether different mechanisms explain the relationships found in health and disease.

$\mathrm{GH}$ resistance is developed during catabolic conditions including major surgery. Bjarnason et al. (21), in a previous study of GHR mRNA during major surgery, found no significant changes of GHR mRNA from day 0 to day 3 after surgery. In a later study they found a significant decrease in GHBP levels and GHR mRNA from day 0 to day 1 after major abdominal surgery (11). There was no apparent explanation for those contrasting data. In the present study tissue biopsy samples were taken within $1-2 \mathrm{~h}$ after surgery was started, and we therefore think that GHR mRNA levels may serve as a steady state measurement of 
GHR mRNA levels. In contrast to fat biopsy samples, blood samples were drawn in the non-fasting state, but since short-term fasting does not influence IGF-I and GHBP levels $(22,23)$, we believe that this is not of major importance for the interpretation of the results.

In conclusion, we have found the expression of the GHR to be identical in intraabdominal and s.c. adipose tissue. In addition we found the number of mRNA transcripts in intraabdominal fat to be inversely correlated to levels of circulating GHBP.

Future studies especially focusing on mutual relationships between $\mathrm{GH}$ secretory status, receptor expression in different tissues, including liver and adipose tissue, and circulating GHBP might further elucidate these complicated mechanisms. We suggest that circulating GHBP is not a reliable index of GHR status in adipose tissue in humans.

\section{Acknowledgements}

The study was supported by the Danish Health Research Council, grant no. 9600822 (Aarhus University-Novo Nordisk Center for Research in Growth and Regeneration). B H was granted a scholarship from the Danish Medical Research Council.

\section{References}

1 Leung D, Spencer S, Cachianes G, Hammonds R, Collins C, Henzel W, Barnard R, Waters M \& Wood W. Growth hormone receptor and serum binding protein: purification, cloning and expression. Nature $1987330537-543$.

2 Dastot F, Sobrier M, Duquesnoy P, Duriez B, Goossens M \& Amselem S. Alternatively spliced forms in the cytoplasmic domain of the human growth hormone $(\mathrm{GH})$ receptor regulate its ability to generate a soluble GH-binding protein. PNAS 1996 93 10723-10728.

3 Ballesteros M, Leung K, Ross R, Iismaa T \& Ho K. Distribution and abundance of messenger ribonucleic acid for growth hormone receptor isoforms in human tissues. Journal of Clinical Endocrinology and Metabolism 200085 2865-2871.

4 Martini J, Villares S, Nagano M, Delehaye-Zervas M, Eymard B, Kelly P \& Postel-Vinay M. Quantitative analysis by polymerase chain reaction of growth hormone receptor gene expression in human liver and muscle. Endocrinology 1995136 1355-1360.

5 Chang T, Lin J, Yu S \& Chang T. Absence of growth-hormone receptor in hepatocellular carcinoma and cirrhotic liver [see comments]. Hepatology 199011 123-126.

6 Donaghy A, Delhanty P, Ho K, Williams R \& Baxter R. Regulation of the growth hormone receptor/binding protein, insulin-like growth factor ternary complex system in human cirrhosis. Journal of Hepatology $200236751-758$.

7 Moller S, Fisker S, Becker U \& Henriksen J. A comparison of circulating and regional growth hormone-binding protein in cirrhosis. Metabolism 200150 1340-1345.

8 Kratzsch J, Blum W, Schenker E \& Keller E. Regulation of growth hormone (GH), insulin-like growth factor (IGF) I, IGF binding proteins $-1,-2,-3$ and $\mathrm{GH}$ binding protein during progression of liver cirrhosis. Experimental and Clinical Endocrinology and Diabetes $1995103285-291$

9 Baruch Y, Amit T, Hertz P, Enat R, Youdim M \& Hochberg Z. Decreased serum growth hormone-binding protein in patients with liver cirrhosis. Journal of Clinical Endocrinology and Metabolism 199173 777-780.

10 Hattori N, Kurahachi H, Ikekubo K, Ishihara T, Moridera K, Hino M, Saiki Y \& Imura H. Serum growth hormone-binding protein, insulin-like growth factor-I, and growth hormone in patients with liver cirrhosis. Metabolism 199241 377-381.

11 Hermansson M, Wickelgren R, Hammarqvist F, Bjarnason R, Wennstrom I, Wernerman J, Carlsson B \& Carlsson L. Measurement of human growth hormone receptor messenger ribonucleic acid by a quantitative polymerase chain reaction-based assay: demonstration of reduced expression after elective surgery. Journal of Clinical Endocrinology and Metabolism $199782421-428$.

12 Fisker S, Kristensen K, Rosenfalck A, Ebdrup L, Richelsen B, Hilsted J, Christiansen J \& Jørgensen J. Gene expression in subcutaneous fat and skeletal muscle of a truncated and the full-length growth hormone $(\mathrm{GH})$ receptor before and after $\mathrm{GH}$ treatment in $\mathrm{GH}$ deficient adults. Journal of Clinical Endocrinology and Metabolism $2000 \mathbf{8 6} 792-796$.

13 Fisker S, Frystyk J, Skriver L, Vestbo E, Ho K \& Ørskov H. A simple, rapid immunometric assay for determination of functional and growth hormone $(\mathrm{GH})$-occupied $\mathrm{GH}$-binding protein in human serum. European Journal of Clinical Investigation $1996 \mathbf{2 6}$ $779-785$.

14 Frystyk J, Dinesen B \& Ørskov H. Non-competitive time-resolved immunofluorometric assays for determination of human insulin-like growth factor I and II. Growth Regulation $1995 \mathbf{5}$ 169-176.

15 Lihn A, Ostergard T, Nyholm B, Pedersen S, Richelsen B \& Schmitz O. Adiponectin expression in adipose tissue is reduced in first-degree relatives of type 2 diabetic patients. American Journal of Physiology. Endocrinology and Metabolism $2003 \mathbf{2 8 4}$ E443-E448.

16 Edens A \& Talamantes F. Alternative processing of growth hormone receptor transcripts. Endocrine Reviews $199819559-582$.

17 Amit T, Bergman T, Dastot F, Youdim M, Amselem S \& Hochberg Z. A membrane-fixed, truncated isoform of the human growth hormone receptor. Journal of Clinical Endocrinology and Metabolism 199782 3813-3817.

18 Vottero A, Kimchi-Sarfaty C, Kratzsch J, Chrousos G \& Hochberg Z. Transcriptional and translational regulation of the splicing isoforms of the growth hormone receptor by glucocorticoids. Hormone and Metabolic Research 200335 7-12.

19 Fisker S, Vahl N, Jørgensen J, Christiansen J \& Ørskov H. Abdominal fat determines growth hormone binding protein levels in healthy non-obese adults. Journal of Clinical Endocrinology and Metabolism 199782 123-128.

20 Johannsson G, Bjarnason R, Bramnert M, Carlsson L, Degerblad M, Manhem P, Rosén T, Thorén M \& Bengtsson B. The individual responsiveness to growth hormone $(\mathrm{GH})$ treatment in GH-deficient adults is dependent on the level of GH-binding protein, body mass index, age, and gender. Journal of Clinical Endocrinology and Metabolism 199681 1575-1581.

21 Bjarnason R, Wickelgren R, Hermansson M, Hammarqvist F, Carlsson B \& Carlsson L. Growth hormone treatment prevents the decrease in insulin-like growth factor I gene expression in patients undergoing abdominal surgery. Journal of Clinical Endocrinology and Metabolism 199883 1566-1572.

22 Aimaretti G, Colao A, Corneli G, Pivonello R, Maccario M, Morrison K, Pflaum C, Strasburger C, Lombardi G \& Ghigo E. The study of spontaneous GH secretion after 36-h fasting distinguishes between GH-deficient and normal adults. Clinical Endocrinology $199951771-777$.

23 Ho P, Gesundheit N, Wong W, Huang S, Friberg R \& Barkan A. Dynamic changes of growth hormone-binding protein concentrations in normal men and patients with acromegaly: effects of short-term fasting. Metabolism 1995 44 667-672.

Received 2 December 2003

Accepted 26 February 2004 